Environmental Disclosure Practices Analysis on Companies Listed on the Indonesia Stock Exchange, Malaysia Exchange, and Thailand Stock Exchange

\title{
Environmental Disclosure Practices Analysis on Companies Listed on the Indonesia Stock Exchange, Malaysia Exchange, and Thailand Stock Exchange
}

\author{
Nensi Febriani ${ }^{1 *}$ and Heri Yanto ${ }^{2}$ \\ ${ }^{1,2}$ Universitas Negeri Semarang, Semarang, Indonesia
}

\begin{abstract}
This study aims to determine differences in environmental disclosure practices in Indonesia, Malaysia, and Thailand and to identify factors that are suspected to influence environmental disclosure, including the size of the board of commissioners, profitability, and company size. The population of this study is large companies listed on the Bursa Efek Indonesia (BEI), the Bursa Malaysia (KLSE), and the Bursa Efek Thailand (SET) which are included in the largest stock market indexes in each exchange in 2018. The sampling method uses purposive sampling so that the research sample is 125 units of analysis. This study uses the One-Way ANOVA analysis and multiple regression analysis using the IBM SPSS 21 program. The results of the study indicate that there are no significant differences in environmental disclosure in Indonesia, Malaysia, and Thailand. The average level of environmental disclosure is $30.67 \%$ and included in the low category. The results of the multiple regression analysis showed that the size of the board of commissioners had a significant positive effect on environmental disclosure, while profitability and company size did not affect environmental disclosure.
\end{abstract}

Keywords: Board of Commissioners Size, Company Size, Environmental Disclosure, Profitability.

\section{Introduction}

Social and environmental disclosure is seen as increasingly important to do because it will have an impact on the company's survival. Ghozali \& Chariri (2014) also explained that the issue of voluntary disclosure in the form of social and environmental disclosures has increased over the past few years. The growing issue has encouraged companies to make more disclosures in their annual reports in addition to reports on the company's finances. With environmental disclosure, the company will benefit one of them is that the level of transparency and accountability of the company will increase, so it will affect the public's view of the company.

Governments in several countries encourage companies to focus more on the environment and publish environmental reports by setting some regulations. Several regulations are governing social and corporate environmental disclosure in Indonesia, one of them is the Law of the Republic of Indonesia Number 40 of 2007 concerning Limited Liability Companies article 66 article 74, Statement of Financial Accounting Standards (PSAK) Number 1 (2012) paragraph 9 concerning Presentation of Financial Statements, and Regulation of the Financial Services Authority No. 51/POJK.03/2017 on The Implementation of Sustainable Finance for Financial Services Institutions, Issuers, and Public Companies. The environmental reporting guidelines in Malaysia are The Accounting Standard Board of Malaysia or Malaysia Accounting Standard Board (MASB) 1 and 20 (Fashikhah, Rahmawati, \& Sofyani , 2018). In 2015 Malaysia also issued a requirement that listed companies must disclose narrative statements on the management of economic materials, environmental and social risks (EES) as well as sustainability report opportunities in published annual reports. Furthermore, in Thailand, in 2008 the Stock Exchange of Thailand (SET) officially required social and

* Corresponding author. Email address : nensifebri98@gmail.com 
environmental reporting in the annual reports of listed companies (Suttipun \& Stanton, 2012b).

Companies that have observed environmental aspects and expressed them are expected to reduce environmental problems (Supriyono \& Suhardjanto, 2014). However, the reality is that some environmental problems that occur involve companies, especially large companies that even fall into the ranks of the largest companies in several countries. In Indonesia, the case of environmental pollution of two mining companies namely PT Stanindo Inti Perkasa who conduct business without an environmental permit and damage the environment due to its business activities so it harms the citizens and PT Indominco Mandiri who dispose of fly ash and bottom ash coal waste in unlicensed places so it pollutes the soil and air (Walhi.or.id, 2018). The case from Thailand is an oil spill caused by an explosion in one of PTTEP Pcl.'s operational areas in the Montara oil field resulting in environmental losses for seaweed farmers and fishermen (Rahmawati \& Budiwati, 2018). Meanwhile, the offshore PTT Global Chemical oil pipeline leak resulted in Rayong province's tourism industry suffering losses estimated at USD70 million (Corben, 2013). Another case in 2014 of PT Adei Plantation and Industry was proven to be negligent resulting in environmental damage (Fashikhah et al., 2018). About 40 hectares of land area in Pelalawan Regency, Riau was damaged. Not only here, on September 7, 2019, forest and land fires again caused the sealing of 4.25 hectares of land in Pelalawan Regency by the Ministry of Environment and Forestry (KLHK), and the impact of the smoke polluted Riau air for several days (Cnn indonesia.com, 2019).

The level of environmental disclosure in each country must vary (Fashikhah et al., 2018). The origin of the country affects the level of flexibility of environmental disclosure due to the role of different laws or regulations in each country (Rahmawati \& Budiwati, 2018). Research from Suhardjanto and Miranti (2009) suggested that listed companies in Indonesia that conduct environmental reporting practices are $53.75 \%$ and overall environmental disclosure level of $4.35 \%$ so it is still very concerning. Djajadikerta and Trireksani (2012) also revealed that the level of social and environmental disclosure of Indonesian companies is still low and most of the disclosures are descriptive, without a specific time frame. Fashikhah et al., (2018) and Buniamin (2010) revealed that environmental disclosure in Malaysia is still low. Research Fashikhah et al., (2018) found that the average environmental disclosure in Indonesia is $6.86 \%$ is higher compared to environmental disclosure in Malaysia of $6.05 \%$. Furthermore, Rahmawati and Budiwati, (2018) conducted a comparative study of mining companies in Indonesia and Thailand and showed the results that environmental disclosure in both countries is still low at a rate of $28.47 \%$. There are different levels of environmental disclosure in both countries based on the number of scores of GRI G4 items. The results showed that mining companies in Thailand care more about the environment. The explanation above shows that the level of environmental disclosure in Southeast Asia is still uneven and tends to be low.

\section{Literature Study}

Research that tests the factors that influence environmental disclosure has been widely conducted and there are still inconsistencies in results. First, the results of Solikhah and Winarsih's research (2016) found a positive influence between the size of the board of commissioners on the quality of environmental disclosure. In line with the research, Fashikhah et al., (2018) also found a positive influence between the size of the board of commissioners and environmental disclosure for samples of Indonesian companies. Meanwhile, the research results of Effendi (2018) and Suprapti, Fajari, and Anwar (2019) showed that the variable size of the board of commissioners does not affect environmental disclosure. Similar results were also shown (Fashikhah et al., 2018) in a sample of Malaysian companies, namely the lack of influence of the board of commissioners' size on environmental disclosure. 
Environmental Disclosure Practices Analysis on Companies Listed on the Indonesia Stock Exchange, Malaysia Exchange, and Thailand Stock Exchange

Second, research by Suhardjanto and Miranti (2009), Aulia and Agustina (2015), and Ismail, Rahman, and Hezabr (2018) found that profitability has a significant positive effect on environmental disclosure. Yanto and Muzzammil (2016) found a negative influence of profitability on environmental reporting. Sulaiman, Abdullah, and Fatima's research (2014) found that profitability has no significant effect on the quality of environmental reporting. In line with that, Deswanto and Siregar (2018) also found that financial performance does not affect environmental disclosure.

The third result of inconsistencies are the company's size variable. Research conducted by (Suttipun \& Stanton, 2012a), Sulaiman et al., (2014), Aulia and Agustina (2015), and Yanto and Muzzammil (2016) showed that the size of the company had a significant positive effect on the area of environmental disclosure, while the research Suhardjanto and Miranti (2009) showed the results of company's size variable did not have a significant effect on the extent of environmental disclosure of the company. Fashikhah et al., (2018) which examined the determinants of environmental disclosure in manufacturing companies in Indonesia and Malaysia showed that the company's size variables had no effect on environmental disclosure on the sample of Indonesian companies, but had a positive effect on the sample of Malaysian companies.

This study aims to find out the differences in environmental disclosure practices in Indonesia, Malaysia, and Thailand and to identify factors that allegedly influence environmental disclosures that include the size of the board of commissioners, profitability, and size of the company. This study took data on companies in Indonesia, Malaysia, and Thailand. Companies in Indonesia, Malaysia, and Thailand were chosen to be objects in this study because the three countries are similar but have different environmental disclosure regulations. The three countries also adopt different systems in the implementation of corporate governance. Indonesia adheres to the Two-Tier System, Malaysia adheres to the One Tier System system while Thailand does not clearly adhere to which system of the two systems (Supriyono \& Suhardjanto, 2014).

The originality of this research is the object of the research which are large companies that are included in the largest stock market indexes on each stock exchange of Indonesia, Malaysia, and Thailand. Then, this study uses the checklist items method and refers to the Global Reporting Initiative (GRI) Standards 2016 environmental aspects in measuring environmental disclosure, where GRI Standards 2016 is the latest guideline for environmental disclosure.

The theory of legitimacy focuses on the interaction between the company and the community (Ghozali \& Chariri, 2014). Legitimacy theory states that organizations are continually looking for ways to ensure their operations are within the limits or norms that apply in society. It is through this environmental disclosure that the company can show a real form of attention to the community and the environment. This will affect the public's view of the company. When the image of the company in the community is getting better, then the legitimacy gap can be overcome by the company so that the company will get support from the community in carrying out its activities.

Agency theory explains the agency relationship between managers (agents) and shareholders (principals) that can lead to high agency costs and information asymmetry. According to Jensen and Meckling (1976), agency fees can arise due to the monitoring activity of the agents' performance by principals, called monitoring costs. Monitoring activities are characterized by a high demand for environmental information. Asymmetry of information took place because the agent knows more information about the company than the principal. To avoid this, a concept of transparency and accountability is needed. Environmental disclosure practices can reduce agency costs and information asymmetry between managers (agents) and principals (Effendi, 2018).

Environmental disclosure in each country varies due to the role of different laws or regulations in each country. Similarly, environmental disclosure in Southeast Asian countries such as Indonesia, Malaysia, and Thailand. Research conducted by Supriyono \& Suhardjanto (2014) in three Southeast Asian countries namely Indonesia, Malaysia, 
and Thailand revealed that there are differences in corporate social disclosure practices in Southeast Asia caused by corporate governance practices.

H1: There are significant differences in environmental disclosure practices at companies in Indonesia, Malaysia, and Thailand

The Board of Commissioners is one of the special organs contained in the corporate governance structure responsible for overseeing the duties of the board of directors (Solikhah \& Winarsih, 2016). The larger the number of members of the board of commissioners, the more effective the supervision carried out, thereby increasing pressure on managers to carry better company management. Through environmental disclosure managers can prove that the management of the company has been running well and show that the business activities carried out by the company are more transparent in providing information for stakeholders and shareholders.

The agency theory reveals that corporate governance can bridge two different sides of interests between the agent and the principal, wherein corporate governance there is corporate social responsibility (CSR) as a form of corporate concern for the society and environment. According to legitimacy theory, the board of commissioners is responsible for supervising management to always act under the expectations and requirements determined by the community, thus encouraging the company to conduct environmental disclosures. Research of Solikhah and Winarsih (2016) and Fashikhah et al., (2018) on Indonesian samples showed a positive influence of the size of the board of commissioners on environmental disclosure.

\section{H2: Board of commissioners' size positively affects environmental disclosure}

The higher the profitability, the more investors attracted to invest their shares, so that the company's responsibility regarding the disclosure of the information is more greatly demanded. In other words, at a time the company can generate profit above the industry average, the company will disclose more information so that creditors and investors are assured that the company's position is in a strong competitive position and its operations are running efficiently (Suhardjanto \& Miranti, 2009). The premise of the agency's theory states that the higher the profit the company earns, the better social disclosures will be. Companies with higher profits mean that they have a large source of funds to make disclosures (Solikhah \& Winarsih, 2016). Research by Aulia and Agustina (2015) and Ismail et al., (2018) also showed that profitability has a positive effect on environmental disclosure.

\section{H3: Profitability positively affects environmental disclosure}

Large companies show more responsibility to society and the environment (Yanto \& Muzzammil, 2016). Environmental disclosure is seen as one form of accountability. Associated with legitimacy theory, large companies tend to get greater attention and pressure from the public due to the impact of their larger operational activities. Associated with agency theory, large companies disclose extensive information so they can reduce agency conflicts. This causes large companies to have greater agency costs compared to small companies. Research by Sulaiman et al., (2014) on companies in Malaysia shows that the size of the company has a significant positive effect on environmental disclosure. Similar results were also shown by the research of Aulia and Agustina (2015), Effendi (2018), Yanto and Muzzammil (2016), Rahmawati and Budiwati (2018), and Fashikhah et al., (2018).

\section{H4: Company size positively affects environmental disclosure}


Environmental Disclosure Practices Analysis on Companies Listed on the Indonesia Stock Exchange, Malaysia Exchange, and Thailand Stock Exchange

\section{Research Methods}

This research is quantitative research using annual report secondary data, integrated report, and CSR / sustainability report of the company. The population of this research is companies listed on the Indonesia Stock Exchange (IDX), Bursa Malaysia (KLSE), and The Stock Exchange of Thailand (SET) which were included in the largest stock market indexes on each exchange in 2018. The largest stock market indexes of each exchange are LQ45 (Indonesia), FBM KLCI (Malaysia), and SET50 (Thailand). The sample was selected using purposive sampling so that a research sample of 125 units of analysis was obtained. The criteria for determining samples are described in the following table 1:

Table 1 Sample Determination Criteria

\begin{tabular}{llll}
\hline No. & Criteria & $\begin{array}{l}\text { Not included in } \\
\text { the Criteria }\end{array}$ & $\begin{array}{l}\text { Included in } \\
\text { the Criteria }\end{array}$ \\
\hline 1. & $\begin{array}{l}\text { Companies listed on the Indonesia Stock Exchange } \\
\text { (IDX), Bursa Malaysia (KLSE), and The Stock Exchange } \\
\text { of Thailand (SET) which were in the largest stock market } \\
\text { index on each exchange for the period 2018 }\end{array}$ & 125 \\
& $\begin{array}{l}\text { Companies that issue integrated annual reports and/or } \\
\text { reports and/or sustainability reports for the period 2018 }\end{array}$ & 125 \\
\hline 2. & \\
\hline Institutions that have complete data related to research & 0 & 125 \\
\hline Analysis unit & & 125 \\
\hline
\end{tabular}

Source: Processed data, 2020

The operational definition of this research variable is presented in the following table 2:

Table 2 Operational Definition of Research Variables

\begin{tabular}{|c|c|c|}
\hline Variables & Definition & Indicator \\
\hline $\begin{array}{l}\text { Environmental } \\
\text { Disclosure (ED) }\end{array}$ & $\begin{array}{l}\text { Disclosure of environmental information } \\
\text { conducted by the company (Solikhah \& } \\
\text { Winarsih, 2016) }\end{array}$ & $\begin{array}{l}\text { Disclosure scoring (Al- } \\
\text { Tuwaijri, Christensen, \& } \\
\text { Hughes, 2004) }\end{array}$ \\
\hline $\begin{array}{l}\text { Board of } \\
\text { Commissioners Size } \\
\text { (UDK) }\end{array}$ & $\begin{array}{l}\text { The number of the board of commissioners } \\
\text { who are members of the company (Fashikhah } \\
\text { et al., 2018). }\end{array}$ & $\begin{array}{l}\text { Total Members of the } \\
\text { Board of } \\
\text { Commissioners(Fashikha } \\
\text { h et al., 2018) }\end{array}$ \\
\hline Profitability (ROA) & $\begin{array}{l}\text { The company's ability to profit from its } \\
\text { business activities (Aulia \& Agustina, 2015). }\end{array}$ & $\begin{array}{l}\text { Return on Asset } \\
\text { Profit After Tax } \\
\text { Total Equity } \\
\text { (Sulaiman et al., 2014; } \\
\text { Rahmawati \& Budiwati, } \\
\text { 2018; Yanto \& } \\
\text { Muzzammil, 2016) }\end{array}$ \\
\hline Company size & $\begin{array}{l}\text { Scale indicating the size of the company } \\
\text { (Aulia \& Agustina, 2015). }\end{array}$ & $\begin{array}{l}\text { LN Total Aset (Sulaiman } \\
\text { et al., 2014) }\end{array}$ \\
\hline
\end{tabular}

Data collection techniques in this study were documentary techniques. The research data was taken from the company's annual report, integrated report, and CSR/sustainability report obtained from the Indonesia Stock Exchange, Bursa Malaysia, and The Thailand Stock Exchange as well as from the official website of each company in the sample. The analytical techniques used in this study are descriptive statistical analysis techniques and inferential statistical analysis. This study 
used descriptive statistics to explain the characteristics of the data and test hypotheses using One-Way ANOVA and multiple regression. Testing was conducted using IBM SPSS 21 program.

\section{Results and Discussions}

The results of descriptive statistic analysis showed that environmental disclosure variables have an average value of 0.306667 or $30.67 \%$. The value indicates that the level of environmental disclosure of large companies in Indonesia, Malaysia, and Thailand is still in the low category. The variable size of the board of commissioners, profitability, and size of the company has an average value of $6.77 ; 0,072030$; and 3.719153. Environmental disclosure variables, the board of commissioners size, and company size have an average value that exceeds the standard deviation value so it can be said that the data distribution of these variables is homogeneous because the deviation of data is relatively small. Profitability variables have a greater standard deviation value than their average value, indicating that the profitability data proxied with ROA is heterogeneous because the deviation of data is quite large compared to the average.

The results of different environmental disclosure tests using One-Way ANOVA resulted in significance values of 0.134 and more than 0.05 so it can be concluded that there are no significant differences in environmental disclosure in Indonesia, Malaysia, and Thailand. Thus the first hypothesis (H1) which states that there are significant differences in environmental disclosure practices in companies in Indonesia, Malaysia, and Thailand is rejected.

Classic assumption tests conducted are a normality test, multicollinearity test, heteroskedasticity test, and autocorrelation test. Normality test using One-Sample Kolmogorov-Smirnov Test with Kolmogorov-Smirnov score result is 1,289 and significant at 0.072 thus showing that the residual data is normally distributed. The multicollinearity test shows that all independent variables have a tolerance value of more than 0.10 and no VIF value exceeds 10 so it can be concluded that there is no independent intervariable multicollinearity in the regression model. The heteroscedasticity test uses a glejser test and shows that the significance value of all independent variables is more than 0.05 so it can be concluded that the regression model does not occur heteroscedasticity. Autocorrelation test using Durbin Watson test (DW test) and produce DW value of 2,025 ( $\mathrm{n}=125, \mathrm{k}=3$, the significance of 5\%) which is greater than the upper limit (du) 1.7574 and less than 2.2426 (4-du) so it can be concluded that there is no autocorrelation in the regression model.

The result of the coefficient of determination indicates the adjusted $\mathrm{R}^{2}$ value of 0.035 . This means that a $3.5 \%$ variation in environmental disclosure variables can be explained by variations in the variable size of the board of commissioners, profitability, and size of the company. While the remaining $96.5 \%$ is explained by other causes outside the research model. The result of multiple regression analysis produces a regression equation in the following equation 1 :

$$
\mathrm{ED}=0,208+0,018 \mathrm{UDK}-0,042 \mathrm{ROA}-0,004 \mathrm{SIZE}+\varepsilon
$$

The results of this research hypothesis test can be seen in Table 3 below:

Table 3 Hypothetical Test Results

\begin{tabular}{llrrr}
\hline Hypothesis & \multicolumn{1}{c}{ Statement } & B & Sig. & Results \\
\hline $\mathrm{H}_{1}$ & $\begin{array}{l}\text { There are significant differences in environmental } \\
\text { disclosure practices at companies in Indonesia, } \\
\text { Malaysia, and Thailand }\end{array}$ & 0,134 & Rejected \\
& & & \\
\hline
\end{tabular}


Environmental Disclosure Practices Analysis on Companies Listed on the Indonesia Stock Exchange, Malaysia Exchange, and Thailand Stock Exchange

\begin{tabular}{|c|c|c|c|c|}
\hline $\mathrm{H}_{2 \mathrm{a}}$ & $\begin{array}{l}\text { The size of the board of commissioners positively } \\
\text { affects environmental disclosure in Indonesia, } \\
\text { Malaysia, and Thailand (combined) }\end{array}$ & 0,208 & 0,010 & Accepted \\
\hline $\mathrm{H}_{2 \mathrm{~b}}$ & $\begin{array}{l}\text { The size of the board of commissioners has a } \\
\text { positive effect on environmental disclosure in } \\
\text { Indonesia }\end{array}$ & 0,017 & 0,351 & Rejected \\
\hline $\mathrm{H}_{2 \mathrm{c}}$ & $\begin{array}{l}\text { The size of board of Commissioners positively } \\
\text { affects environmental disclosure in Malaysia }\end{array}$ & $-0,008$ & 0,698 & Rejected \\
\hline $\mathrm{H}_{2 \mathrm{~d}}$ & $\begin{array}{l}\text { The size of board of Commissioners positively } \\
\text { affects environmental disclosure in Thailand }\end{array}$ & 0,019 & 0,037 & Accepted \\
\hline $\mathrm{H}_{3 \mathrm{a}}$ & $\begin{array}{l}\text { Profitability positively affects environmental } \\
\text { disclosure in Indonesia, Malaysia, and Thailand } \\
\text { (combined) }\end{array}$ & $-0,042$ & 0,884 & Rejected \\
\hline $\mathrm{H}_{3 b}$ & $\begin{array}{l}\text { Profitability positively affects environmental } \\
\text { disclosure in Indonesia }\end{array}$ & 0,011 & 0,975 & Rejected \\
\hline $\mathrm{H}_{3 \mathrm{c}}$ & $\begin{array}{l}\text { Profitability positively affects environmental } \\
\text { disclosure in Malaysia }\end{array}$ & 0,657 & 0,387 & Rejected \\
\hline $\mathrm{H}_{3 \mathrm{~d}}$ & $\begin{array}{l}\text { Profitability positively affects environmental } \\
\text { disclosure in Thailand }\end{array}$ & $-0,441$ & 0,443 & Rejected \\
\hline $\mathrm{H}_{4 \mathrm{a}}$ & $\begin{array}{l}\text { The size of the company has a positive effect on } \\
\text { environmental disclosure in Indonesia, Malaysia, } \\
\text { and Thailand (combined) }\end{array}$ & $-0,004$ & 0,908 & Rejected \\
\hline $\mathrm{H}_{4 \mathrm{~b}}$ & $\begin{array}{l}\text { The size of the company has a positive effect on } \\
\text { environmental disclosure in Indonesia }\end{array}$ & $-0,013$ & 0,829 & Rejected \\
\hline $\mathrm{H}_{4 \mathrm{c}}$ & $\begin{array}{l}\text { Company size positively affects environmental } \\
\text { disclosure in Malaysia }\end{array}$ & $-0,002$ & 0,977 & Rejected \\
\hline $\mathrm{H}_{4 \mathrm{~d}}$ & $\begin{array}{l}\text { Company size positively affects environmental } \\
\text { disclosures in Thailand }\end{array}$ & 0,019 & 0,799 & Rejected \\
\hline
\end{tabular}

Source: Processed data, 2020

Differences in Environmental Disclosure Practices in Indonesia, Malaysia, and Thailand

The results showed that there were no significant differences in environmental disclosure in Indonesia, Malaysia, and Thailand. This condition occurs because the three countries use the same guidelines in environmental disclosure, namely Global Reporting Initiatives (GRI). Based on the observations of researchers, most major companies in Indonesia, Malaysia, and Thailand in this study sample in 2018 used GRI Standards 2016 guidelines in conducting environmental disclosure.

The Effect of the Board of Commissioners' Measure on Environmental Disclosure

The size of the board of commissioners has a positive effect on environmental disclosure in Indonesia, Malaysia, and Thailand (combined). The larger the number of members of the board of commissioners, the more effective the supervision carried out. Increasingly effective supervision of the company's activities will make the company more orderly in terms of disclosure (Fashikhah et al., 2018). The more members of the board of commissioners will be more supportive of the implementation of environmental disclosure.

The results support the agency's theory that the company provides accountability to two different sides of interests between the agent and the principal by using the corporate governance system, in which there is corporate social responsibility (CSR) as a form of corporate concern for the society and environment. Environmental disclosure itself is part of CSR. The results also support the theory of legitimacy which states that companies through environmental disclosure ensure their operations are within the limits or norms that apply in society. Therefore, the board of commissioners 
is responsible for supervising management to always act under the expectations and requirements determined by the community, so that the company can continue to maintain its legitimacy in the eyes of the community.

The size of the board of commissioners has no effect on environmental disclosure for Indonesian samples. The results of this study are in accordance with the results of research from Effendi (2018). According to Effendi (2018), the reason why the size of the board of commissioners does not affect environmental disclosure is that there are still companies that do not apply legislation governing the size of the board of commissioners. In addition to that, although Indonesia adheres to a two-tier system, the board of commissioners and the board of directors are equal because according to the Limited Liability Company Act of 1995 they are jointly responsible for the GMS. This parallel position resulted in the supervisory function of the board of commissioners not running effectively so that the practice of environmental disclosure is not maximal.

The size of the board of commissioners does not affect environmental disclosures for Malaysian samples. The results of this study are in accordance with the results of Fashikhah et al., (2018) which found that the size of the board of commissioners has no effect on environmental disclosure for Malaysian samples. The Board of Commissioners does not have a definite interest in environmental disclosure, so a large number of commissioners in a company does not mean anything because only a handful pay attention to environmental aspects and focus on environmental disclosure (Fashikhah et al., 2018). Also, according to Fashikhah et al., (2018), the number of commissioners who are too large will be more difficult in the decision-making process, the number of ideas or thoughts of each board of commissioners will need more time to draw one conclusion so that the performance becomes less effective. This supports the results of research that shows the variable size of the board of commissioners in Malaysia has a negative regression coefficient value of -0.008 . The more members of the board of commissioners, the lower the level of corporate environmental disclosure will be. Regarding the form of the board, Malaysia adheres to a one-tier system, in which the company has a board that is a combination of managers and independent directors. The commissioner's position is aligned and is on a board with management, so the commissioner's control is less robust in encouraging management to conduct environmental disclosures.

The size of the board of commissioners had a significant positive effect on environmental disclosure for the Thai sample. The Board of Commissioners has a considerable role in corporate governance. The position of the board of commissioners in Thailand is proven necessary to improve management to conduct and inform its environmental activities. Also, the form and board system adopted by companies in Thailand is considered more flexible because, in terms of corporate governance, the company can adapt the principles of good corporate governance according to the functional needs of each company. These results are in accordance with the results of research Solikhah and Winarsih (2016).

\section{The Effect of Profitability on Environmental Disclosure}

Profitability has no effect on environmental disclosure in Indonesia, Malaysia, and Thailand (combined). The level of profitability does not affect the company's efforts in making environmental disclosures. Environmental disclosure is not a meaningful focus for the companies. The company's main focus is profit to improve performance and maintain its market capitalization. Another reason is that the company deliberately does not disclose information related to its environment widely so as not to interfere with stakeholders in looking at the company's good financial performance (Yanto \& Muzzammil, 2016). The results of this study are not in line with the agency's theory that the higher the profit earned by the company, the disclosure will be even better.

Profitability has no effect on environmental disclosure for Indonesian samples. These results are in line with the research of Deswanto and Siregar (2018). Strong financial performance is indicated by high returns, but it is not an incentive for 
Environmental Disclosure Practices Analysis on Companies Listed on the Indonesia Stock Exchange, Malaysia Exchange, and Thailand Stock Exchange

companies to increase their environmental disclosures or in other words companies do not use profits as a consideration when they make environmental disclosures (Deswanto \& Siregar, 2018).

Profitability has no effect on environmental disclosure for Malaysian samples. These results are in line with Sulaiman et al.'s research, (2014) related to the determinant of the quality of environmental disclosure in Malaysia. The results found that profitability has no significant relationship to the quality of environmental disclosure because companies in Malaysia consider environmental information is not economically beneficial to their business.

Profitability has no effect on environmental disclosure for Thai samples. The ROA regression coefficient value of -0.441 indicates that the increase in ROA is opposite to the decreasing level of corporate environmental disclosure. In agreement with Purwanto (2011), the company's high ROA level is not necessarily allocated for social and environmental activities so that the level of corporate responsibility related to society and the environment is still low. The company's perspective and policy on disclosure are factors that influence the relationship of profitability with environmental disclosure. Some companies consider that environmental disclosure will only reduce profit. The results of this study were supported by a comparative study of Rahmawati and Budiwati (2018).

\section{The Effect of Company Size on Environmental Disclosure}

The company's size has no effect on environmental disclosure in Indonesia, Malaysia, and Thailand (combined). Fontana. D'Amico, Coluccia, and Solimeneet (2015) revealed that large companies tend to provide more information about the environment only if they produce more environmental pollution, to legitimize themselves from stakeholders. The types of companies' samples in this study ranged from service companies, trading companies, manufacturing companies, and other types. Not all companies in the sample have or produce the same operational impact, so in terms of environmental disclosure, the resulting environment will be different in complexity. This was the main cause of the company's lack of effect on environmental disclosure in this study.

The company's size has no effect on environmental disclosure for Indonesian samples. The size of the company does not indicate that the company is capable of conducting environmental-related activities and conducting environmental disclosures. Some companies have considerable assets but do not do many environmentally related activities and report them. There are also companies with smaller assets but can do environmental activities and report them more. The results of this study are in accordance with the results of research by Suhardjanto and Miranti (2009).

The company's size has no effect on environmental disclosures for Malaysian samples. The reason that can be used as the basis for the results of this test is that large companies do not necessarily make broad environmental disclosures if the company does not consider that environmental disclosure policy as a favorable policy because environmental disclosure is still voluntary (Fashikhah et al., 2018). Environmental report in Malaysia is still initiative and voluntary. Regarding the lack of standard guidelines on the form of environmental reports that companies must publish, it is still freedom for companies to report anything related to environmental information.

The company's size does not affect environmental disclosures for Thai samples. There is an assumption that companies with small assets will still make environmental disclosures to influence public view, with the intention that the company's image to remain good in the public eye. Also, according to Loh, Thao, Sim, Thomas, and Yu (2016) Thailand is considered to have the highest quality of sustainability disclosure in ASEAN because it has a business culture that strongly emphasizes compliance and incorporates social and environmental responsibility into the company's vision and mission. This indicates that Thai companies will still make environmental disclosures regardless the size of the company. 


\section{Conclusion}

Different test results showed that there were no significant differences in environmental disclosure in Indonesia, Malaysia, and Thailand. This condition occurs because most major companies in Indonesia, Malaysia, and Thailand in this research sample in 2018 used GRI Standards 2016 guidelines in conducting environmental disclosures. The main factors influencing environmental disclosure in Southeast Asia, especially in Indonesia, Malaysia, and Thailand, are the size of the board of commissioners, while the profitability and size of the company have no effect. Therefore, the company should maximize the role of its board of commissioners through clear positions and functions in accordance with the system adopted by the company in each country, so that it is expected to be able to encourage management to conduct environmental disclosures.

An average environmental disclosure rate of $30.67 \%$ indicates that the environmental disclosure rate of large companies in Indonesia, Malaysia, and Thailand is still relatively low. This is because the company's awareness of environmental disclosure is not evenly distributed which is characterized by environmental problems caused by the company's operational activities and there are even companies that do not make environmental disclosures. The role of regulation and government is indispensable in making environmental disclosure an important and mandatory part for the survival of the company and the environment.

\section{References}

Al-Tuwaijri, S. A., Christensen, T. E., \& Hughes, K. E. (2004). The relations among environmental disclosure, environmental performance, and economic performance: A simultaneous equations approach. Accounting, Organizations and Society, 29(5-6), 447-471. https://doi.org/10.1016/S0361-3682(03)00032-1

Aulia, F. Z., \& Agustina, L. (2015). Pengaruh Karakteristik Perusahaan, Kinerja Lingkungan, dan Liputan Media Terhadap Environmental Disclosure. Accounting Analysis Journal, 4(3).

Buniamin, S. (2010). The Quantity and Quality of Environmental Reporting in Annual Report of Public Listed Companies in Malaysia. Issues In Social And Environmental Accounting, 4(2), 115. https://doi.org/10.22164/isea.v4i2.50

Cnnindonesia.com. (2019). Jejak Panas nan Membara Perusahaan Sawit Malaysia di Riau. $\quad$ https://www.cnnindonesia.com/nasional/20190914133014-20430476/jejak-panas-nan-membara-perusahaan-sawit-malaysia-di-riau

Corben, R. (2013). Aktivis Lingkungan Desak Thailand Perketat Regulasi Industri Minyak. https://www.voaindonesia.com/a/aktivis-lingkungan-desak-thailandperketat-regulasi/1714029.html

Deswanto, R. B., \& Siregar, S. V. (2018). The associations between environmental disclosures with financial performance, environmental performance, and firm value. Social Responsibility Journal, 14(1), 180-193. https://doi.org/10.1108/SRJ-01-2017-0005

Djajadikerta, H. G., \& Trireksani, T. (2012). Corporate social and environmental disclosure by Indonesian listed companies on their corporate web sites. In Journal of Applied Accounting Research (Vol. 13, Issue 1, pp. 21-36). https://doi.org/10.1108/09675421211231899

Effendi, B. (2018). Ukuran Perusahaan, Dewan Komisaris Dan Environmental Disclosure. Jurnal Riset Akuntansi Tirtayasa, 1-19. 
Environmental Disclosure Practices Analysis on Companies Listed on the Indonesia

Stock Exchange, Malaysia Exchange, and Thailand Stock Exchange

Fashikhah, I., Rahmawati, E., \& Sofyani, H. (2018). Determinan Environmental Disclosures Perusahaan Manufaktur di Indonesia dan Malaysia. Jurnal Akuntansi Indonesia, 7(1), 31-55.

Fontana, S., D’Amico, E., Coluccia, D., \& Solimene, S. (2015). Does environmental performance affect companies' environmental disclosure? Measuring Business Excellence, 19(3), 42-57. https://doi.org/10.1108/MBE-04-2015-0019

Ghozali, I., \& Chariri, A. (2014). Teori Akuntansi: International Financial Reporting System (IFRS) (4th ed.). Badan Penerbit Universitas Diponegoro.

Ismail, A. H., Rahman, A. A., \& Hezabr, A. A. (2018). Determinants of corporate environmental disclosure quality of oil and gas industry in developing countries. International Journal of Ethics and Systems, 34(4), 527-563. https://doi.org/10.1108/IJOES-03-2018-0042

Jensen, M. C., \& Meckling, W. H. (1976). Theory of the Firm : Managerial Behavior, Agency Costs and Ownership Structure. Journal of Financial Economics, 3(4), 305-360. http://papers.ssrn.com/abstract $=94043$

Loh, L., Thao, N. T. P., Sim, I., Thomas, T., \& Yu, W. (2016). Pelaporan yang Berkelanjutan di Asean. Journal Nasional University of Singapur, 1-28. https://doi.org/10.1007/s00216-011-5191-0

Purwanto, A. (2011). Pengaruh Tipe Industri, Ukuran Perusahaan, Profitabilitas, Terhadap Corporate Social Responsiblity. Jurnal Akuntansi \& Auditing, 8(1).

Rahmawati, S., \& Budiwati, C. (2018). Karakteristik Perusahaan, ISO 14001, dan Pengungkapan Lingkungan: Studi Komparatif di Indonesia dan Thailand. Jurnal Akuntansi Dan Bisnis, 18(1), 74. https://doi.org/10.20961/jab.v18i1.268

Solikhah, B., \& Winarsih, A. M. (2016). Pengaruh Liputan Media, Kepekaan Industri, dan Struktur Tata Kelola Perusahaan terhadap Kualitas Pengungkapan Lingkungan. Jurnal Akuntansi Dan Keuangan Indonesia. https://doi.org/10.21002/jaki.2016.01

Suhardjanto, D., \& Miranti, L. (2009). Indonesian Environmental Reporting Index. Jurnal Akuntansi Dan Auditing Indonesia, 13(1), 63-67.

Sulaiman, M., Abdullah, N., \& Fatima, A. H. (2014). Determinants of Environmental Reporting Quality in Malaysia. IIUM Journal of Economics and Management, 22(1), 63-90.

Suprapti, E., Fajari, F. A., \& Anwar, A. S. H. (2019). Pengaruh Good Corporate Governance Terhadap Environmental Disclosure. Akuntabilitas: Jurnal Ilmu Akuntansi Volume $12 \quad$ (2), $2019 \quad$ P-ISSN:, 12(2), 215-226. https://doi.org/10.15408/akt.v12i2.13225

Supriyono, E., \& Suhardjanto, D. (2014). Praktik pengungkapan sosial: Studi komparatif di Asia Tenggara. Jurnal Siasat Bisnis, 17(2), 187-207. https://doi.org/10.20885/jsb.vol17.iss2.art5

Suttipun, M., \& Stanton, P. (2012a). Determinants of Environmental Disclosure in Thai Corporate Annual Reports. International Journal of Accounting and Financial Reporting, 2(1), 99. https://doi.org/10.5296/ijafr.v2i1.1458

Suttipun, M., \& Stanton, P. (2012b). Making or not making environmental disclosures in Thailand. International Journal of Business and Social Science, 3(9), 73-81.

Walhi.or.id. (2018). Putusan Jauh dari Asas Keadilan, Koalisi Desak Negara Lakukan 
Upaya Banding. https://www.walhi.or.id/putusan-jauh-dari-asas-keadilankoalisi-desak-negara-lakukan-upaya-banding-2

Yanto, H., \& Muzzammil, B. S. (2016). A long way to implement environmental reporting in Indonesian Mining companies. International Journal of Applied Business and Economic Research, 14(10), 6493-6513. https://doi.org/10.2139/ssrn.2908974 